\title{
An experts' opinion-based comparison and benefit cost analysis of post-mortem versus tuberculin skin test surveillance systems, Mpumalanga, South Africa
}

\section{Rudo Marange}

University of Pretoria

Folorunso Fasina ( $\nabla$ daydupe2003@yahoo.co.uk)

Food and Agriculture Organization of the United Nations https://orcid.org/0000-0003-3088-8752

Bjorn Reininghaus

Mpumalanga Provincial Government

Darshana Morar-Leather

University of Pretoria

\section{Research}

Keywords: bovine tuberculosis, benefit cost analysis, Mpumalanga, surveillance, zoonosis

Posted Date: June 17th, 2020

DOl: https://doi.org/10.21203/rs.3.rs-34964/v1

License: (c) (i) This work is licensed under a Creative Commons Attribution 4.0 International License. Read Full License 


\section{Abstract}

\section{Background}

Tuberculosis (TB) is a global health concern caused mostly by Mycobacterium bovis (M. bovis) and Mycobacterium tuberculosis (M. tuberculosis) in animals and humans respectively. As part of TB control strategies, most governments instituted test and slaughter policies for bovine TB (bTB) eradication with varied level of success.

\section{Methods}

Using the SurvCost ${ }^{\circledR}$ (http://www.cdc.gov/idsr/survcost.htm), we evaluated the postmortem surveillance (PMS) system as an alternative to the tuberculin skin test (TST). Experts'opinions survey was used to collect information on the perceived level of acceptability of PMS and TST, successes and challenges of both surveillance systems, economic and budget data. Benefit cost analysis of both systems were evaluated and the comparative economic benefit of PMS over TST was determined.

\section{Results}

TST implementation was challenging due to poor logistics, procurement challenge, poor feedback, inconsistency in testing and poor return rate for retesting. Experts agreed that PMS was cheaper but almost impracticable due to late detection and probable poor compliance rate but farmers were more open to PMS than TST. Personnel cost remains the largest part of the surveillance cost (47.8\% of total costs). TST and PMS systems can be up to 4.40 and 5.96 times more beneficial that not tackling bTB respectively and PMS is 1.35 more cost beneficial that TST.

\section{Conclusion}

While TST is empirical, compliance by farmers was poor due to the associated inconveniences. In the alternative, PMS was convenient for farmers but experts believed that adherence will be poor unless increased manpower is available. We advocated for a blended approach between the two systems. Improved field surveillance and detailed economic data should benefit future economic assessment.

\section{Trial registration}

Not applicable.

\section{Background}

Mycobacterium bovis (M. bovis) is the causal agent for bovine tuberculosis (bTB), an infectious and chronic disease of livestock, wildlife and humans [1,2]. M. bovis is a significant pathogen due to its conservation threat (wildlife infections), economic implication (cattle disease), and zoonotic importance. Bovine TB remains a worldwide problem, therefore it is imperative to intensify control and preventive measures in livestock aimed at its eradication [3].

The TST is recognised universally and used for preliminary diagnosis in bTB control programmes [4]. Other tests include antibody ELISAs and Bovigam ${ }^{\circledR}{ }^{\mathrm{Tm}}$ (a commercial IFN-g assay), used as ancillary tests in eradication and control of bTB [4]. In South Africa the TST is accepted as the standard field test for diagnosis in bTB control programmes. The advantages of the TST and reasons for its extensive use are low costs, relatively better accessibility of tuberculin purified protein derivative (PPD), history of successful use, and the lack of better alternative methods to detect bTB [5]. Despite these advantages the skin test has many known limitations, including the difficulties in field administration and interpretation of results, the need for a supplementary visit to measure the skin response and associated non-compliance by farmers, a low degree of standardisation, and imperfection associated with test accuracy $[5,6]$. As such, its field application appears unpopular among the field veterinarians and their paraveterinary staff [7].

Eradication of bTB from cattle in some countries has been unexpectedly protracted, and this has raised questions about the effectiveness of skin testing, particularly when the incidence of disease in the population is low or where there is the potential for 
contact with environmental mycobacteria. Given the above, recent research has focused on developing alternative, innovative, and complementary testing procedures [2,8].

It has been shown that in countries with low bTB, disease prevalence or disease-free status, meat inspection is effective as a diagnostic and surveillance tool [4]. The importance and impact of meat inspection as a diagnostic and preventive tool cannot be overemphasized. In addition to providing epidemiological information on life threatening zoonotic diseases of meat-borne origin, such as bovine TB, brucellosis, and other toxicoinfections (such as salmonellosis), it also ensures standards for hygienic and wholesome meat free from infections and other toxicoses of inorganic sources are met and upheld [9].

In 2015, Musoke and colleagues performed a bTB surveillance study on cattle in the Mnisi Community, based in the Bushbuckridge District Municipality, Mpumalanga province, South Africa [10]. They found a low prevalence (approx. $0.34 \%$, excluding suspect animals) of bTB in the cattle population. This low prevalence in cattle may justify the use of point-of-slaughter postmortem evaluation in communal areas for diagnosis and surveillance. VanderWaal et al. [11] studied different surveillance strategies such as PMS and targeted testing as alternatives to routine skin testing in low TB prevalence settings. They found that targeted surveillance was more cost effective and reduced sampling effort by $40 \%$ without increasing the incidence of bTB.

Currently, in the Mnisi Community in the Bushbuckridge Municipality of Mpumalanga province, the TST surveillance in cattle is minimally applied due to high costs and unwillingness to conduct the difficult TST by technicians (personal communication with professionals). This is not an unusual phenomenon. O'Reilly \& Daborn [1] have noted that the TST is not always performed as recommended because of management conditions that make it difficult to perform. Furthermore, bTB TST evaluation has focused on cattle [12; other livestock species such as goats and sheep have been neglected though they are susceptible to M. bovis [13].

In some parts of Africa, bTB detection has depended on slaughter surveillance as the most economical and efficient method for the detection of infected cattle [14]. Meat inspection at abattoirs is thus considered as a pivotal and the utmost obligatory method for the detection of bTB or other mycobacterial infections [14]. In view of the foregoing and considering that such PMS systems, which are seen as cheaper and easier to perform, are adapted to rural communities at the point of personal slaughter and not just at the abattoirs, we sought to investigate if this would be a more cost effective and efficacious detection method for TB surveillance versus the current bTB TST in the Mnisi Community which has achieved poor compliance in TST? Also, would the veterinarians and para-veterinarians consider this procedure a less laborious and easily adaptable method? Outcome can serve as a proof of concept to geographical terrains with similar situations.

\section{Materials And Methods}

\section{Expert opinion survey}

To get a representative opinion of the acceptability of the proposed postmortem surveillance system, a questionnaire directed at government officials (veterinary directors, state veterinarians and technicians) from all nine provinces of South Africa was developed. Questionnaires were administered by email or by telephonic interview. It included open-ended and closed questions, which focused on the current budget for TST surveillance, challenges faced with the surveillance program, opinion on an incentivebased PMS system and a panel of questions on logistic and other issues that support the application and administration of the current programme.

\section{Benefit cost analysis}

Budget data were obtained from the State Veterinary services. Additional prevailing economic data were retrieved either through field survey or personal interviews with the stakeholders in the industry. Population and other demographic data as well as prevalence of TB in Mnisi, Mpumalanga or South Africa were obtained through literature review and from the website of Statistics South Africa (www.statssa.gov.za). Using budget information from State Veterinary services, all costs (recurrent, operational and capital expenditure) were calculated under different cost heads (Supplementary data). An annual summary of all costs was generated as outputs, and an integrated disease surveillance cost for TB was produced based on field data using the SurvCost ${ }^{\circledR}$, an Excel-based analysis tool (http://www.cdc.gov/idsr/survcost.htm). Integrated Disease Surveillance and Response System (IDSR) is a system whereby all diseases of interest in an area through passive or active surveillance are reported together using the same

Page $3 / 11$ 
human, capital and infrastructure resources already available to the area [15]. SurvCost ${ }^{\circledR}$ uses this system to estimate surveillance costs of diseases of interest. Outputs were generated in tables and graphs. Comparative costs and effectiveness were evaluated using the benefit cost analyses of overall estimated surveillance costs using TST and PMS.

\section{Results}

\section{Expert opinion survey}

Ten experts that included directors of veterinary services, state veterinarians and animal health technicians (AHT) in the South African Veterinary Services participated in the expert opinion survey. A response rate of $67 \%$ was obtained. In view of the sensitivity of budget matters, and stringent rules regarding non-disclosure, it was a challenge to obtain some detailed budget information from technical experts. While some feigned ignorance or referred the researcher to higher authorities, others ignored the question completely. However, detailed information was obtained from two provinces and this formed the basis for comparison and validation of economic data.

Ninety percent of all experts had a bTB surveillance program operational in the areas covered by their operations. The TST is most used as recommended by DAFF for South African Veterinary Services [16].

The main challenges of the TST reported by participants include among others: poor logistics in the implementation of the herd testing program, centralised and red tape in the procurement system for reagents (tuberculin), lack of timeous feedback to central agency (DAFF) and no consistency in frequency of testing.

Overall, $90 \%$ of all experts suggested that a PMS system is impracticable and not good for adoption. Reasons advanced for opposing the PMS were: it detects infection very late and so may enhance spread, farmers would use their own resources to report pending slaughter and this might result in low compliance, slaughter rates are low, there will be too many homesteads to follow up, attitude of farmers varies and there are illiterate farmers who may not take the strict implementation seriously, manpower and transport would be a challenge, and that some mortalities may not be reported.

The experts agreed that the TST is not being implemented effectively due to the above cited challenges, but do not see PMS as a viable and practical alternative.

\section{Benefit Cost Analysis}

Using SurvCost ${ }^{\circledR}$, an integrated disease surveillance and response system implemented for TST will cost R1,783, 242 per annum for the Mnisi Community with an average cost of R84.33 per animal. Specifically, 35.4\% of the cost will be for personnel, $16.0 \%$ for office support, $7.5 \%$ for transport, $30.9 \%$ for test sundries (i.e tuberculin ,syringes, gloves), $0.2 \%$ for treatment and $9.9 \%$ as capital cost (Table 1, Figures1 and 2). For a similar programme implemented for PMS, the overall cost will reduce to R1,320,361 per annum with an average cost of R62.44 per animal. In this case, $47.8 \%$ of the cost will be for personnel, $21.7 \%$ for office support, $15.6 \%$ for transport, $1.3 \%$ for test sundries, $0.3 \%$ for treatment and $13.4 \%$ as capital cost (Table 1, Figures 1 and 2 ).

In both graphs, (Figures $2 \& 3$, Supplementary material), personnel costs were the highest by proportions. In TST surveillance, the costs of tuberculin added significantly to the test sundries cost while in PMS, the test sundries costs decrease proportionately to approximately $1 \%$ since there was no need for the skin test. However, the cost for transport increased proportionately in PMS due to costs incurred in door to door communal slaughter postmortem inspections. Overall, in this study, the PMS model appears cheaper than the TST model.

The 2017 estimates of cattle population in Mnisi will be 21,145 and at a 3.1\% prevalence of bTB in cattle, approximately 656 heads of cattle will be infected (Musoke et al., 2015); at a market value of approximately R12 000 per cow, a hypothetical 100\% rejection of infected cattle population will result in losses of R7,872,000. Even, at $50 \%$ or $25 \%$ rejection rates, assumed losses will amount to $\mathrm{R} 3,936,000$ or R1,968,000 respectively (Table 2). Through the integration of TST and PMS, the benefit cost ratio will be 4.41 or 5.96 respectively. While it is evident that conducting the annual surveillance is better in both respects using TST or PMS, the latter (PMS) was at least 1.35 fold economically cost beneficial compared with TST (Table 2). Below a $25 \%$ rejection rate of the infected animals, the surveillance system becomes non-beneficial for implementation in the Mnisi Community. Similarly, surveillance using 
TST or PMS based on visceral (lungs and livers) rejection alone cannot justify the investment as inputs far outweigh the expected benefit. (Table 2). Additional benefits including the deduction in risk of transmission to other animals and prevention of 339 potential human cases were not quantified in this analysis.

Table 1. SurvCost ${ }^{\circledR}$ cost analysis for TST and PMS for bovine tuberculosis based on inputs from experts

\begin{tabular}{|c|c|c|c|c|c|}
\hline \multicolumn{2}{|l|}{ Category } & \multicolumn{2}{|l|}{ Current TST system costs } & \multicolumn{2}{|c|}{ Proposed PMS system cost } \\
\hline & & $\begin{array}{l}\text { All disease surveillance } \\
\text { cost }\end{array}$ & $\begin{array}{l}\text { TB IDSR } \\
\text { cost }\end{array}$ & $\begin{array}{l}\text { All disease surveillance } \\
\text { cost }\end{array}$ & $\begin{array}{l}\text { TB IDSR } \\
\text { cost }\end{array}$ \\
\hline & & $(\mathrm{ZAR})$ & $(\mathrm{ZAR})$ & $(\mathrm{ZAR})$ & $(\mathrm{ZAR})$ \\
\hline \multirow{5}{*}{$\begin{array}{l}\text { Recurrent } \\
\text { costs }\end{array}$} & Personnel & 1490587 & 630902 & 1491956 & 630902 \\
\hline & Office & 722274 & 286009 & 722274 & 286009 \\
\hline & Transport & 356375 & 134389 & 365375 & 205896 \\
\hline & $\begin{array}{l}\text { Laboratory /Test } \\
\text { sundries }\end{array}$ & 637397 & 551217 & 56100 & 16830 \\
\hline & Treatment & 49564 & 4371 & 49564 & 4371 \\
\hline \multirow[t]{2}{*}{ Capital costs } & Buildings & 38876 & 5831 & 38876 & 5831 \\
\hline & Vehicles & 365389 & 170522 & 365389 & 170522 \\
\hline All resources & & 3661831 & 1783242 & 3080534 & 1320361 \\
\hline Cost per anim & & 173.18 & 84.33 & 145.69 & 62.44 \\
\hline
\end{tabular}

PMS = postmortem surveillance and TST = tuberculin skin test system

Table 2. Benefit-cost analysis of comparison between postmortem surveillance (PMS) and tuberculin skin test (TST), Mpumalanga, South Africa 


\begin{tabular}{|c|c|c|c|c|c|c|c|c|c|}
\hline s/no. & Items & $\begin{array}{l}\text { PMS } \\
\text { (in } \\
\text { ZAR) }\end{array}$ & $\begin{array}{l}\text { Total } \\
\text { (in } \\
\text { ZAR) }\end{array}$ & $\begin{array}{l}\text { Benefit/ } \\
\text { cost } \\
\text { (PMS) }\end{array}$ & $\begin{array}{l}\text { TST } \\
\text { (in } \\
\text { ZAR) }\end{array}$ & $\begin{array}{l}\text { Total } \\
\text { (in } \\
\text { ZAR) }\end{array}$ & $\begin{array}{l}\text { Benefit/ } \\
\text { cost } \\
\text { (TST) }\end{array}$ & $\begin{array}{l}\text { Comments/Additional } \\
\text { benefits }\end{array}$ & $\begin{array}{l}\text { Source(s) } \\
\text { of } \\
\text { information }\end{array}$ \\
\hline 1 & $\begin{array}{l}\text { Cost of } \\
\text { surveillance for } \\
\text { TB/animal/annum }\end{array}$ & 62.44 & & & 84.33 & & & & $\begin{array}{l}\text { SurvCost }{ }^{\circledR} \\
\text { analysis, } \\
\text { this work }\end{array}$ \\
\hline 2 & $\begin{array}{l}\text { Total number of } \\
\text { animal } 2017 \\
\text { estimate }\end{array}$ & $\begin{array}{l}21 \\
145\end{array}$ & $\begin{array}{l}1320 \\
294\end{array}$ & & $\begin{array}{l}21 \\
145\end{array}$ & $\begin{array}{l}1783 \\
158\end{array}$ & & \multirow{2}{*}{$\begin{array}{l}\text { Cattle population } \\
\text { estimate for } 2017 \\
\text { was obtained using } \\
\text { cattle population in } \\
\text { Mnisi for } 2013(n=12 \\
832) \text { and annual } \\
\text { growth rate }(n=13.3) \\
\text { to estimate for year } \\
2014-2017 \text {. } \\
\text { Prevalence rate of } \\
3.1 \% \text { was used. }\end{array}$} & \multirow[t]{2}{*}[10,17]{} \\
\hline 3 & $\begin{array}{l}\text { Total number of } \\
\text { animal involved at } \\
3.1 \% \text { prevalence } \\
\text { rate of TB }\end{array}$ & 656 & & & 656 & & & & \\
\hline 4 & $\begin{array}{l}\text { Mean cost of a } \\
\text { cow in rural South } \\
\text { Africa }\end{array}$ & $\begin{array}{l}12 \\
000\end{array}$ & & & $\begin{array}{l}12 \\
000\end{array}$ & & & $\begin{array}{l}\text { Prevailing market } \\
\text { price of adult Nguni } \\
\text { cow at auction/rural } \\
\text { South Africa (R10 } 500 \\
\text { - R12 000). }\end{array}$ & $\begin{array}{l}\text { Market } \\
\text { survey, } \\
2017\end{array}$ \\
\hline 5 & $\begin{array}{l}\text { Total cost of } \\
\text { animals involved } \\
\text { (100\% loss) }\end{array}$ & & $\begin{array}{l}7872 \\
000\end{array}$ & 5.96 & & $\begin{array}{l}7872 \\
000\end{array}$ & 4.41 & \multirow{4}{*}{$\begin{array}{l}\text { Number of human } \\
\text { cases was obtained } \\
\text { using total human } \\
\text { population estimate } \\
\text { for } 2015 \text { ( } \mathrm{n}=80,000) \text {, } \\
\text { annual growth rate } \\
(10.9 \% \text { over } 4 \text { years; } \\
2.75 \% \text { per annum) } \\
\text { and incidence rate of } \\
\text { TB in humans for } \\
\text { Mpumalanna } \\
(0.4 \%) \text {. Reduction in } \\
\text { risk of transmission } \\
\text { to other animals }+ \\
\text { prevention of } 339 \\
\text { human cases are } \\
\text { additional benefits } \\
\text { not quantified in this } \\
\text { analysis }\end{array}$} & \multirow[t]{4}{*}{ [18-20] } \\
\hline 6 & $\begin{array}{l}\text { Total cost of } \\
\text { animals involved } \\
\text { (50\% loss) }\end{array}$ & & $\begin{array}{l}3936 \\
000\end{array}$ & 2.98 & & $\begin{array}{l}3936 \\
000\end{array}$ & 2.21 & & \\
\hline 7 & $\begin{array}{l}\text { Total cost of } \\
\text { animals involved } \\
\text { ( } 25 \% \text { loss) }\end{array}$ & & $\begin{array}{l}1968 \\
000\end{array}$ & 1.49 & & $\begin{array}{l}1968 \\
000\end{array}$ & 1.10 & & \\
\hline 8 & $\begin{array}{l}\text { Total cost of } \\
\text { animals involved } \\
\text { (10\% loss) }\end{array}$ & & $\begin{array}{l}787 \\
200\end{array}$ & 0.60 & & $\begin{array}{l}787 \\
200\end{array}$ & 0.44 & & \\
\hline
\end{tabular}

Cost of partial rejection alone in Mnisi Community, Mpumalanga/annum

\begin{tabular}{|c|c|c|c|c|c|c|c|c|}
\hline 9 & $\begin{array}{l}\text { Cost of lungs } / \mathrm{kg} \\
\text { (ZAR) }\end{array}$ & 38 & & & 38 & & & [21] \\
\hline 10 & $\begin{array}{l}\text { Average weight of } \\
\text { lung in a standard } \\
\text { cow }(\mathrm{kg})\end{array}$ & 7.8 & 296.4 & & 7.8 & 296.4 & & \\
\hline 11 & $\begin{array}{l}\text { Total costs for } 656 \\
\text { lungs }\end{array}$ & & $\begin{array}{l}194 \\
438\end{array}$ & & & $\begin{array}{l}194 \\
438\end{array}$ & & [10] \\
\hline 12 & Cost of liver/kg & 35 & & & 35 & & & \\
\hline 12 & $\begin{array}{l}\text { Average weight of } \\
\text { liver in a standard } \\
\text { cow }(\mathrm{kg})\end{array}$ & 6.9 & 241.5 & & 6.9 & 241.5 & & \\
\hline 14 & $\begin{array}{l}\text { Total costs for } 656 \\
\text { livers }\end{array}$ & & $\begin{array}{l}158 \\
424\end{array}$ & & & $\begin{array}{l}158 \\
424\end{array}$ & & [10] \\
\hline 15 & $\begin{array}{l}\text { Total costs (lungs } \\
+ \text { livers) }\end{array}$ & & $\begin{array}{l}352 \\
862\end{array}$ & 0.27 & & $\begin{array}{l}352 \\
862\end{array}$ & 0.20 & [10] \\
\hline
\end{tabular}

Relative ratio of PMS to TST is 1.35 , meaning that it is approximately 1.35 times cheaper to institute PMS with relatively equal benefit than to institute TST. ZAR = South African Rand. 


\section{Discussion}

The experts confirmed that cattle are the most tested animals and the TST is most used test but agreed that the test is underimplemented and not effectively carried out. A review of the implementation strategies and reasons for non-compliance will need further evaluation. It will also be necessary to include all susceptible animals in such a surveillance programme. Furthermore, key challenges have been identified and efforts will need to be engaged to overcome these issues. Because outbreaks of other statecontrolled diseases (foot and mouth disease, rabies, and brucellosis) divert attention from bTB surveillance, a comprehensive or integrated surveillance system that incorporates all the potential endemic diseases may need to be implemented. On the low level of compliance with second time visits by farmers, intensive awareness campaigns may achieve some degree of success. However, because farmers will prefer PMS, and experts will want a continuation of the TST, a blended approach combining these two surveillance systems may need to be assessed as no stakeholder can be ignored with regards to effective surveillance. It will be important for experts to also pay attention to gathering detailed field level data for future epidemiological evaluations. In the present survey, only $40 \%$ of the experts have verifiable prevalence data. It should be understood that the diptanks present excellent opportunity for the collation of such epidemiological data.

This study provides economic justification for the implementation of surveillance against bTB in the first instance, and showed evidence that PMS is cheaper than the TST.

It is approximately six times and four times more beneficial to perform the PMS and the TST surveillances respectively than to allow the spread of bTB in the Mnisi Community without any control. Mwacalimba, Mumba \& Munyeme [22] have reported that taking into consideration only the monetary value of a cow at point of sale, there is a positive cost-benefit to the control of bTB. If a broader approach is considered such as the impact of TB on human health and tourism in TB affected wildlife, there is no doubt that costs associated with TB control are minimal compared to the benefits of eradicating TB [22]. In this analysis, even for $25 \%$ level of losses, it is beneficial to conduct surveillance against TB; however, lower level losses do not justify surveillance in this respect. This may partially explain why countries with low TB prevalences or disease-free status undertake meat inspection only as a cheap alternative for TB surveillance system [4].

It is agreed that this benefit cost analysis has certain limitations because it does not take into account the broader benefits of performing surveillance such as reducing zoonotic disease risk, human loss in quality of life and productivity when sick, loss in animal production, milk and meat yields, loss in tourism and conservation when wildlife species are affected. These may serve as additional reasons to justify surveillance in the Mnisi Community. Mpumalanga has a human TB incidence rate of $0.4 \%$ and this translates to 339 human infections in Mnisi Community. The control of TB in animals could potentially prevent a proportion of these human cases [18-20].

\section{Conclusion}

Finally, both models have their own merits and challenges. The PMS model would need increased manpower and transport resources while the TST has not been effective due to difficulty in implementation and low level of compliance. As the TST currently achieves low effectiveness in South Africa, merging the two surveillance systems remains a viable surveillance option. The most effective and cheapest way of controlling zoonotic diseases is to control it at the animal source, and this study may be used as a baseline for future studies to find more effective ways to control bTB in resource-poor or rural communities, and enhance the 'End TB' strategy [23].

\section{Abbreviations}

AHT: animal health technicians

bTB: Bovine Tuberculosis

DAFF: Department of Agriculture, Forestry and Fisheries, South Africa

ELISA: Enzyme-linked immunosorbent assay

Page $7 / 11$ 
IDSR: Integrated Disease Surveillance and Response System

IFN: Interferon

PMS: postmortem surveillance

PPD: purified protein derivative

TB: Tuberculosis

TST: tuberculin skin test.

\section{Declarations}

\section{Ethical approval and consent to participate}

The project was approved by the University of Pretoria Animal Ethics Committee (AEC), (certificate number v116-16) and Human Ethics Committee (certificate number 374/2016). All participants in the survey signed the consent form for participation.

\section{Availability of data}

All data associated with this work are available in the supplementary materials and tool online submitted with this manuscript. Furthermore, the full MSc (Tropical Animal Health) dissertation by Marange Rudo, from which this work was generated titled ' $A$ comparison of perceptions of the tuberculin skin test and an incentive postmortem based surveillance system in the Mnisi community, Mpumalanga', is available at the Department of Veterinary Tropical Diseases, Faculty of Veterinary Science, University of Pretoria and is permanently archived in the open access repository of the University of Pretoria (UPeTD).

\section{Competing interest}

The authors declare no conflict of interest that should stop the review or publication of the manuscript.

\section{Funding}

The student (RM) and the research was funded by the Belgian Development Cooperation Agency (RM) and National Research Foundation, South Africa (NRF) incentive funding (DM-L \& FOF).

\section{Authors' contributions}

FOF and DM-L supervised the study. RM collected the field data. FOF \& RM conducted the benefit-cost analysis. All authors contributed to the design of the study, writing of the manuscript and approved the submission.

\section{Consent for publication}

All author read and approved the manuscript for submission to and publication in the journal Cost Effectiveness and Resource Allocation. The authorities involve have no hesitation to publishing the findings from the study.

\section{Acknowledgements}

We acknowledge and appreciate the following people and institutions for their input and support: the Mnisi community, University of Pretoria projects facilitation team including Jacques van Rooyen, llana van Wyk, Jeanette Wentzel, and the environmental monitors who translated and facilitated engagements with the community. Special thanks to the Mpumalanga State Veterinary Services including Mr. Solly Mokone, the animal health controller and all the technicians for giving us access to their operational data and allowing us to conduct the study during their dipping sessions. Finally, we are grateful to the Belgian Development Cooperation Agency and NRF incentive funding for financing this research.

\section{References}


1. O'Reilly LM, Daborn CJ. The epidemiology of Mycobacterium bovis infections in animals and man: a review. Tubercle and Lung disease. 1995 Aug 1;76:1-46.

2. Neill SD, Skuce RA, Pollock JM. Tuberculosis-new light from an old window. Journal of applied microbiology. 2005;98(6):12619.

3. Humblet MF, Boschiroli ML, Saegerman C. Classification of worldwide bovine tuberculosis risk factors in cattle: a stratified approach. Veterinary research. 2009 Sep 1;40(5):1-24.

4. Ayele WY, Neill SD, Zinsstag J, Weiss MG, Pavlik I. Bovine tuberculosis: an old disease but a new threat to Africa. The International Journal of Tuberculosis and Lung Disease. 2004 Aug 1;8(8):924-37.

5. Schiller I, Oesch B, Vordermeier HM, Palmer MV, Harris BN, Orloski KA, Buddle BM, Thacker TC, Lyashchenko KP, Waters WR. Bovine tuberculosis: a review of current and emerging diagnostic techniques in view of their relevance for disease control and eradication. Transboundary and emerging diseases. 2010 Aug;57(4):205-20.

6. De la Rua-Domenech R, Goodchild AT, Vordermeier HM, Hewinson RG, Christiansen KH, Clifton-Hadley RS. Ante mortem diagnosis of tuberculosis in cattle: a review of the tuberculin tests, $y$-interferon assay and other ancillary diagnostic techniques. Research in veterinary science. 2006 Oct 1;81(2):190-210.

7. Marange R. A comparison of perceptions of the tuberculin skin test and an incentive postmortem-based surveillance system in the Mnisi community, Mpumalanga, South Africa, 2019 (Master's thesis)

8. Pollock JM, McNair J, Welsh MD, Girvin RM, Kennedy HE, Mackie DP, Neill SD. Immune responses in bovine tuberculosis. Tuberculosis. 2001 Feb 1;81(1-2):103-7.

9. Sa'idu AS, Mohammed S, Ashafa M, Gashua MM, Mahre MB, Maigado Al. Retrospective study of bovine tuberculosis in Gombe township abattoir, Northeastern Nigeria. International journal of veterinary science and medicine. 2017 Jun 1;5(1):65-9.

10. Musoke J, Hlokwe T, Marcotty T, Du Plessis BJ, Michel AL. Spillover of Mycobacterium bovis from wildlife to livestock, South Africa. Emerging infectious diseases. 2015 Mar;21(3):448.

11. VanderWaal K, Enns EA, Picasso C, Alvarez J, Perez A, Fernandez F, Gil A, Craft M, Wells S. Optimal surveillance strategies for bovine tuberculosis in a low-prevalence country. Scientific reports. 2017 Jun 23;7(1):1-2.

12. Nyoni G, Questionnaire-based study to determine the state of tuberculosis testing in goats in South Africa. 2019 (Master's thesis).

13. Napp S, Allepuz A, Mercader I, Nofrarías M, López-Soria S, Domingo M, Romero B, Bezos J, De Val BP. Evidence of goats acting as domestic reservoirs of bovine tuberculosis. Veterinary Record. 2013 May 17.

14. Shitaye JE, Tsegaye W, Pavlik I. Bovine tuberculosis infection in animal and human populations in Ethiopia: a review. VETERINARNI MEDICINA-PRAHA-. 2007 Aug 1;52(8):317.

15. Phalkey RK, Yamamoto S, Awate P, Marx M. Challenges with the implementation of an Integrated Disease Surveillance and Response (IDSR) system: systematic review of the lessons learned. Health policy and planning. 2015 Feb 1;30(1):131-43.

16. Department of Agriculture Forestry And Fisheries 2016. Bovine Tuberculosis Manual.

17. Gaudex L. University of Pretoria; South Africa: 2014. A Health and Demographic Surveillance System of Cattle on Communal Rangelands in Bushbuckridge, South Africa: Baseline Census and Population Dynamics Over 12 Months. MSc. dissertation.

18. Statistics South Africa 2015, < www.statssa.gov.za>, accessed 1 November 2017

19. National Institute for Communicable Diseases: Annual Overview 2014/2015. Available at: https://www.nicd.ac.za/wpcontent/uploads/2017/10/NHLS_Annual_Report_2015_NIDC.pdf. accessed 14 April 2017, 80p

20. World Health Organisation 2017, End TB Strategy: Global Tuberculosis Report, 2017, Available at: https://www.who.int/tb/publications/global_report/gtbr2017_main_text.pdf?ua=1, accessed 14 April 2017, 147p.

21. Jaja, I. F., Mushonga, B., Green, E., \& Muchenje, V. (2016). Prevalence of lung lesions in slaughtered cattle in the Eastern Cape Province, South Africa. Journal of the South African Veterinary Association, 87(1), e1-e9.

https://doi.org/10.4102/jsava.v87i1.1362

22. Mwacalimba KK, Mumba C, Munyeme M. Cost benefit analysis of tuberculosis control in wildlife-livestock interface areas of Southern Zambia. Preventive veterinary medicine. 2013 Jun 1;110(2):274-9. 
23. Welburn SC, Beange I, Ducrotoy MJ, Okello AL. The neglected zoonoses-the case for integrated control and advocacy. Clinical Microbiology and Infection. 2015 May 1;21(5):433-43.

\section{Figures}

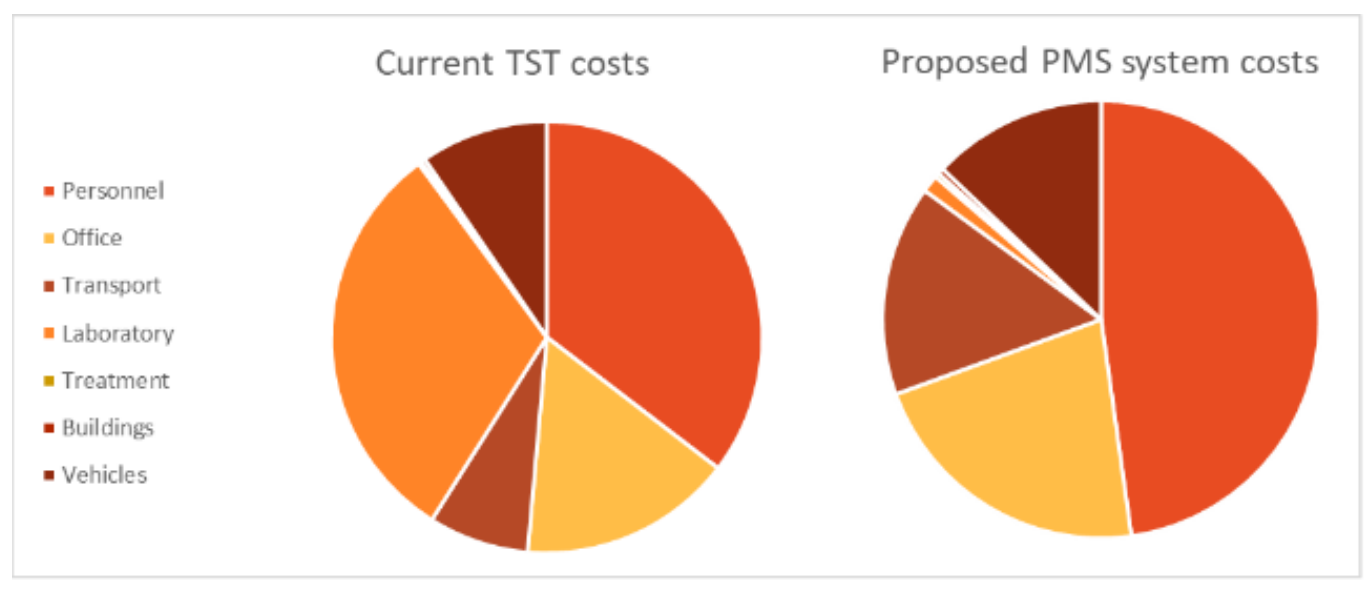

\section{Figure 1}

Comparison of current TST system costs versus proposed PMS system costs in Mnisi Community, Mpumalanga province as proportion of total IDSR program cost for animal disease surveillance, 2017 estimates

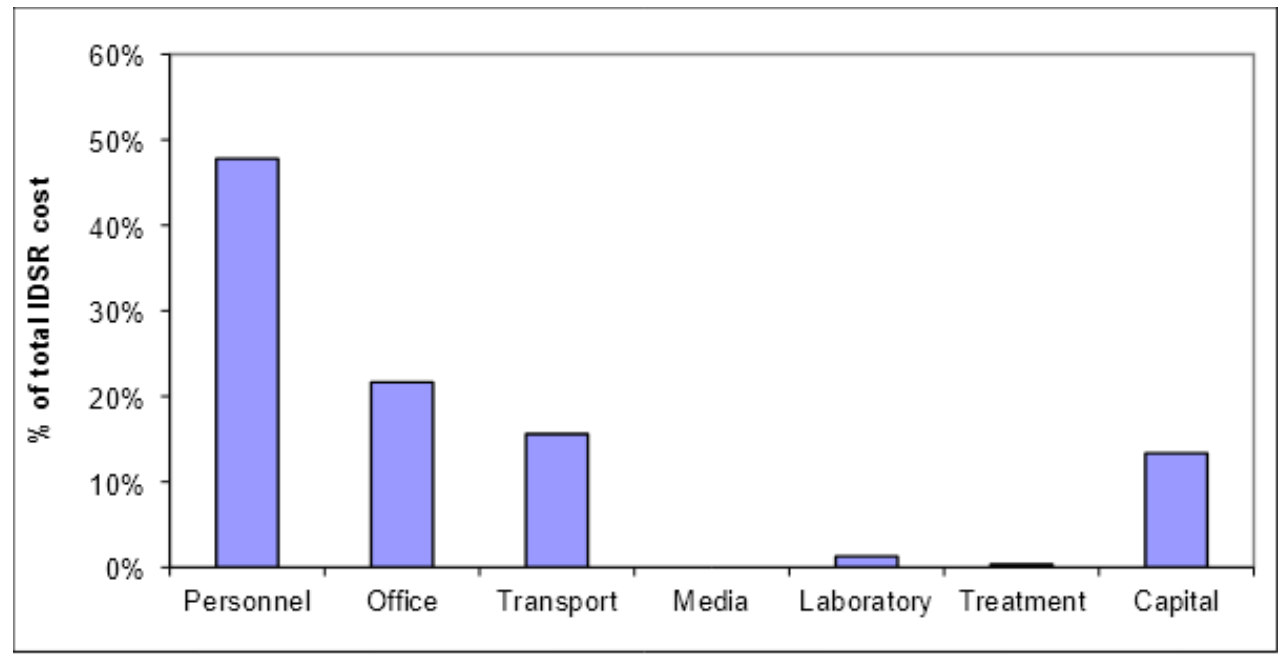

\section{Figure 2}

TST system costs in Mnisi Community, Mpumalanga province as proportion of total IDSR program cost for animal disease surveillance, 2017 estimates 


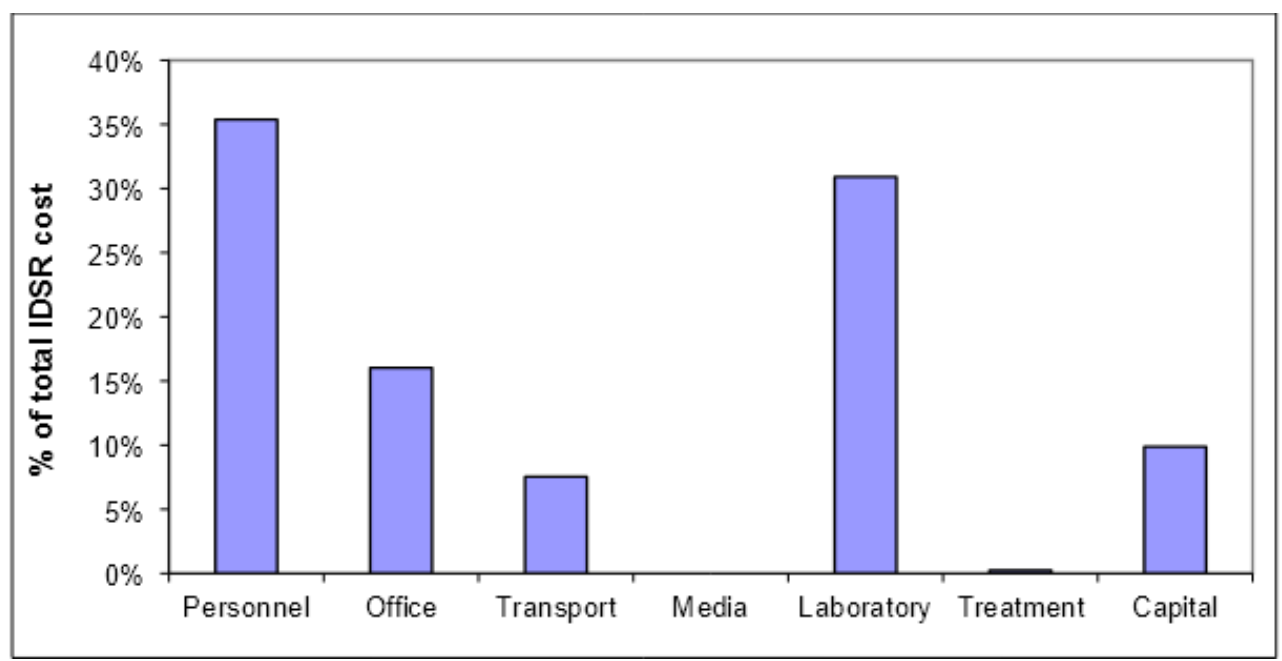

\section{Figure 3}

PMS system costs in Mnisi Community, Mpumalanga province as proportion of total IDSR program cost for animal disease surveillance, 2017 estimates

\section{Supplementary Files}

This is a list of supplementary files associated with this preprint. Click to download.

- supplement8.xls 